Note

\title{
Cytotoxicity of Extracts from Alternaria alternata against Cultured Tobacco BY-2 Cells
}

\author{
KI-BONG OH ${ }^{1}$, YASUO TAJIMA ${ }^{2}$, MIKAKO SAITO ${ }^{2}$, \\ IL-MOO CHANG ${ }^{1}$, AND HIDEAKI MATSUOKA ${ }^{2}$ \\ 'Natural Products Research Institute, Seoul National University, 28 Yungun-dong, \\ Jongro-ku, Seoul 110-460, Korea and ${ }^{2}$ Department of Biotechnology, \\ Faculty of Technology, Tokyo University of Agriculture \\ and Technology, 2-24-16, Nakamachi, Koganei, \\ Tokyo 184-8588, Japan
}

Received 2 August 2001/Accepted 17 December 2001

The cytotoxicity of extracts from Alternaria alternata against tobacco Bright Yellow-2 (BY2) cells was investigated by a simultaneous double-staining procedure using fluorescein diacetate and propidium iodide. The active fraction from a 10-day-old culture filtrate of the fungus was purified by ammonium sulfate precipitation, ultrafiltration, gel filtration on Sephadex G-10, and reversed-phase HPLC, in sequence. The partially purified principle appears to be heat- and acid-stable, as neither incubation at $100^{\circ} \mathrm{C}$ for $30 \mathrm{~min}$ nor overnight treatment at pH 2 altered the cytotoxicity. The cytotoxicity of the principle was abolished after treatment with proteinase $\mathrm{K}$ or trypsin, while the dithiothreitol treatment showed reduced cytotoxicity.

Key words : Alternaria alternata/Metabolite/BY-2 cells/Cytotoxicity.

Fungal toxins play an important role in the pathogenesis of plants. The fungus Alternaria alternata has been reported to cause various phytotoxic effects during pathogenesis, including chlorosis or necrosis on leaves and other parts of the plant, as well as inhibition of seed germination (Abbas et al., 1998; Hasan, 2001; Knogge, 1996; Kohmoto et al., 1991). At least seven host-specific phytotoxins, which the fungus produces while attacking respective hosts, have been reported. Host-specific phytotoxins, produced by more than 10 species of fungal pathogens, include relatively low molecular cyclodepsipeptides, terpenopeptides and unbranched long chain polyketols and esters of organic acids with long chain alcohols (Kodoma et al., 1998; Kohmoto et al., 1993; Liakopoulou-Kyriakides et al., 1997; Liebermann et al., 1996; Suemitsu et al. 1990; Walton, 1996; Yagi et al., 1993). For example, tentoxin is a tetrapeptide produced by the fungus $A$. alternata, which is a potent in-

*Corresponding author. Tel : +82-2-740-8915, Fax : +82-2745-1015 hibitor of the chloroplastic ATP synthase of certain sensitive plant species (Koncewicz et al., 1973; Meyer et al., 1971; Steele et al., 1976). In addition $A$. alternata excretes dihydrotentoxin, the precusor of tentoxin, which contains $\mathrm{N}$-methyl-L-phenylalanine, and other related compounds, including a cyclic dipeptide of N-methyl-L-phenylalanine and leucine, non-peptide compounds and conjugates between tentoxin and non-peptides (Ramm et al., 1994). Tenuazoic acid (TeA) is also one of the most important Alternaria mycotoxins found in nature. It has been suggested that the principle mode of action of TeA toxin appears to be the suppression of the release of newly formed proteins from the ribosome (Combina et al., 1999; Li et al., 2001). During our investigation on bioactive compounds from fungal metabolites, it was found that the fungus $A$. alternata produces peptide-like substances indicating a cytotoxic activity against the tobacco cell line BY-2 derived from Nicotiana tabacum L. cv. Bright Yellow 2. Therefore, we initiated a study in order to elucidate the toxin profiles of the $A$. alternata metabolites, as described 
below.

A. alternata 102, which was used in this study, was obtained from Hatano Research Institute, Food and Drug Safety Center, Kanagawa, Japan, and was maintained on potato-dextrose agar (Difco). For toxin production, $A$. alternata 102 was grown on modified Linsmaier and Skoog medium (1965) (LSD medium, $\mathrm{pH}$ 5.8, Linsmaier and Skoog medium containing $9 \times$ $10^{-9} \mathrm{M}$ 2,4-dichlorophenoxyacetic acid and 3\% sucrose). A $3 l$ flask containing $1 l$ of LSD liquid medium was inoculated with $5 \times 10^{7}$ viable spores resuspended in $0.15 \%(\mathrm{v} / \mathrm{v})$ Tween 80 . The culture was incubated for 10 days at $28^{\circ} \mathrm{C}$ on an orbital shaker (120 rpm) and was harvested by filtration through Whatman GF/A glass microfiber filters (10 $l$ ). The protein of the culture filtrate was precipitated overnight with $85 \%\left(\mathrm{NH}_{4}\right)_{2} \mathrm{SO}_{4}$. The resulting precipitate was collected by centrifugation at $10,000 \times g$ for $30 \mathrm{~min}$ and dissolved in the smallest possible volume of $50 \mathrm{mM}$ phosphate buffer ( $\mathrm{pH} 5.8)$. The sample was ultrafiltered $\left(2,000 \times g, 4^{\circ} \mathrm{C}, 20 \mathrm{~h}\right)$ using an Ultrafree-4 centrifugal filter unit equipped with a highflux Biomax membrane (nominal molecular-mass cutoff, 10,000 Da; Millipore). The low molecular-mass fraction containing cytotoxic activity was concentrated by lyophilization and loaded onto a Sephadex G-10 column ( $2 \times 10 \mathrm{~cm}$, Pharmacia Biotech) equilibrated in pure water. The active fractions were pooled and applied to a reversed-phase HPLC TSKgel ODS$80 \mathrm{~T}_{\mathrm{M}}$ column $(0.46 \times 15 \mathrm{~cm}$, Tosoh Co., Tokyo $)$ connected to a Hewlett Packard HPLC system (HP 1100 series). Adsorbed material was eluted with a linear gradient of $0-100 \%$ acetonitrile in water at a flow rate of $0.3 \mathrm{ml} / \mathrm{min}$. Peptides in the column effluents were monitored by measuring the absorbance at $216 \mathrm{~nm}$. Fractions of $0.3 \mathrm{ml}$ were collected, and those containing cytotoxic activity were stored at $-80^{\circ} \mathrm{C}$.

The suspension of the tobacco BY-2 cells was cultured as described in Ishida et al. (1993). Cells were cultured for 3 days at $28^{\circ} \mathrm{C}$, collected by centrifugation at $120 \times g$ for $2 \mathrm{~min}$, and washed 2 times with LSD medium. The pellet was finally suspended in the same medium at a concentration of $6 \times 10^{5}$ cells $/ \mathrm{ml}$. One hundred and eighty $\mu$ I aliquots of this cell suspension were gently poured into a 24 -well plate and combined with another $20 \mu$ I of LSD medium containing various concentrations of $A$. alternata metabolites. After incubation for $4 \mathrm{~h}$ at $28^{\circ} \mathrm{C}$, the cytotoxicity levels in the test samples were determined by a simultaneous doublestaining procedure using fluorescein diacetate (FDA, Sigma) and propidium iodide (PI, Sigma) (Jones and Senft, 1985). A stock solution of FDA was prepared by dissolving $5 \mathrm{mg} / \mathrm{ml}$ in dimethyl sulfoxide. The FDA working solution was freshly prepared by adding 0.04 $\mathrm{ml}$ of stock to $10 \mathrm{ml}$ of phosphate buffered saline (PBS). One milligram of $\mathrm{Pl}$ was dissolved in $50 \mathrm{ml}$ of PBS. To stain with FDA-PI, $0.1 \mathrm{ml}(2 \mu \mathrm{g})$ of the FDA working solution and $0.03 \mathrm{ml}(0.6 \mu \mathrm{g})$ of $\mathrm{Pl}$ were added directly to the cell suspensions. One hundred viable (green)/nonviable (red) cells were counted and the means of the counts recorded. FDA-PIstained cells were examined with a standard fluorescence microscope equipped with epi-illumination, a 100W halogen bulb, band pass 450-490 nm exciter filter, $510 \mathrm{~nm}$ chromatic beam splitter, and long pass $520 \mathrm{~nm}$ barrier filter. This filter combination permitted both green and red fluorescing cells to be seen simultaneously.

The cytotoxic principle of $A$. alternata was purified by a four-step procedure. The first step involved ammonium sulfate precipitation with $85 \%$ relative saturation. In the second step, the precipitate was dissolved in $50 \mathrm{mM}$ phosphate buffer and passed through an ultrafiltration column. The low molecular-mass fraction ( $<10,000 \mathrm{Da})$ containing cytotoxic activity was further separated in a third step by the Sephadex G-10

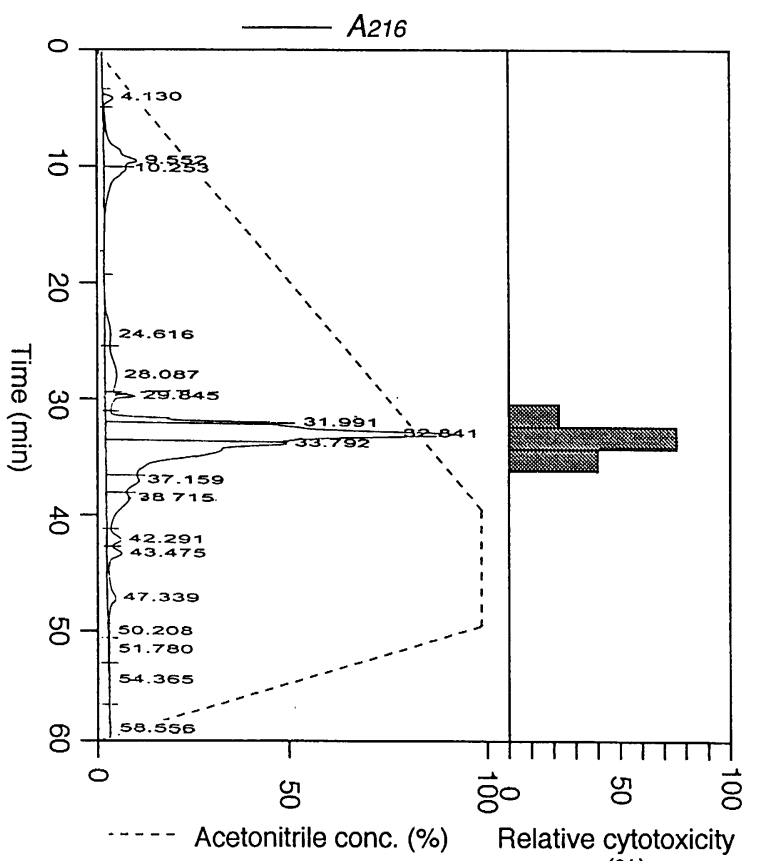

(\%)

FIG. 1. Reversed-phase HPLC chromatogram of the cytotoxic principle ( $\mathrm{Aa}$-CTP) from Sephadex G-10 column chromatography. About $0.5 \mathrm{mg}$ of the active protein fraction was loaded on a TSKgel ODS-80T ${ }_{M}$ column $(0.46 \times 15 \mathrm{~cm}$, Tosoh Co., Tokyo). The column was eluted at $0.3 \mathrm{ml} / \mathrm{min}$ with a linear gradient of $0-100 \%$ acetonitrile in water. The elute was monitored for peptides by on-line measurement of the absorption at $216 \mathrm{~nm}$. Each fraction $(0.6 \mathrm{ml})$ of the elute was collected, vacuum-dried, dissolved in $20 \mu \mathrm{I}$ water and used in the cytotoxicity assay (upper panel). 
column (useful $M$, fractionation range $<700$ ). The active fractions were purified in the final step by reversed-phase chromatography on a $\mathrm{C}_{18}$ silica column (Fig. 1). The active factor partially purified from reversed-phase HPLC is hereby referred to as $A a-$ CTP (A. alternata cytotoxic peptide). Aa-CTP was assessed for its cytotoxic potency on the tobacco BY-2 cell line derived from Nicotiana tabacum L. cv. Bright Yellow 2. In this study, the BY-2 cell line is particularly suitable for analyzing the cytotoxic principle because it grows rapidly, shows high synchrony in cell division and is sensitive to toxic compounds (Fig. 2). Another evaluation method of cytotoxicity by using the LSL929 cell line was also found in our research, and in the near future, we would like to try to evaluate this assay method. Enzymatic digestion experiments revealed that the cytotoxicity of $\mathrm{Aa}$-CTP was abolished after treatment with proteinase $\mathrm{K}$ or trypsin as shown in Fig. 3. In contrast, Aa-CTP was not affected by heat
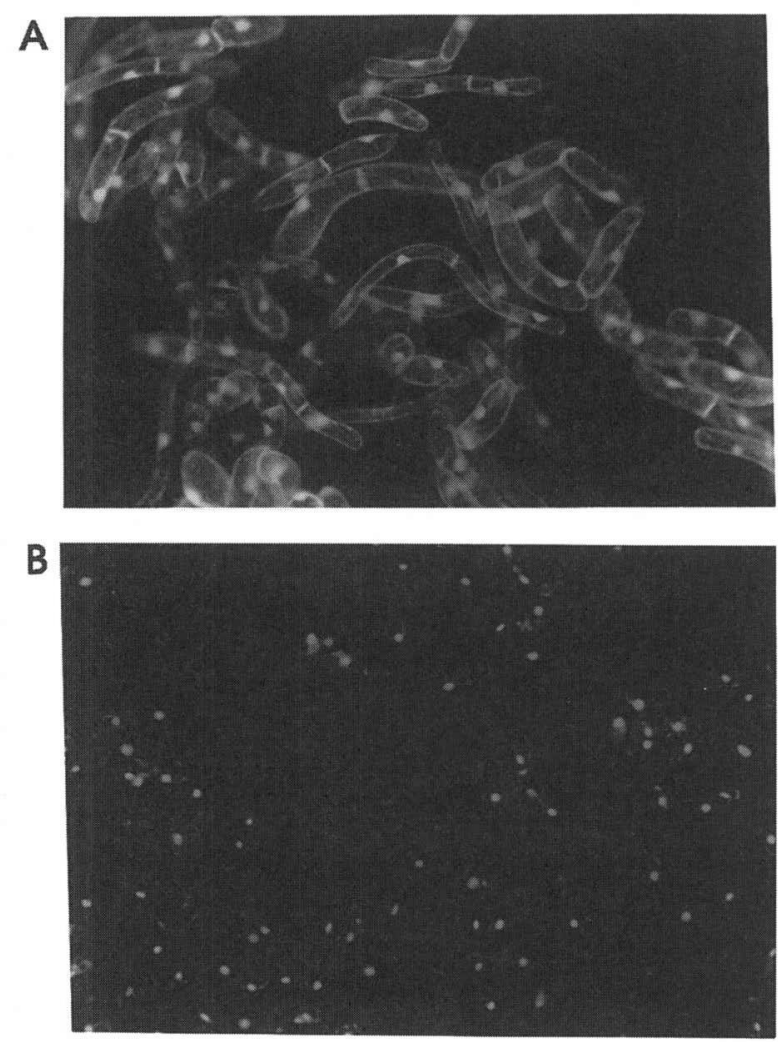

FIG. 2. Fluorescence microscopic images of tobacco BY-2 cells after being double stained with FDA and PI. One hundred and eighty microliter aliquots of the BY-2 cell suspension $\left(6 \times 10^{5} \mathrm{cells} / \mathrm{ml}\right.$, LSD medium) were combined with another $20 \mu \mathrm{I}$ of LSD or $20 \mu \mathrm{I}$ of LSD medium containing Aa-CTP partially purified by HPLC and incubated for $4 \mathrm{~h}$ at $28^{\circ} \mathrm{C}$. A: control (without $A a-C T P$ ); living cell; FDA fluorescence. B: with Aa-CTP (final concn, $40 \mathrm{\mu g} / \mathrm{ml}$ ); dead cell; $\mathrm{PI}$ fluorescence.

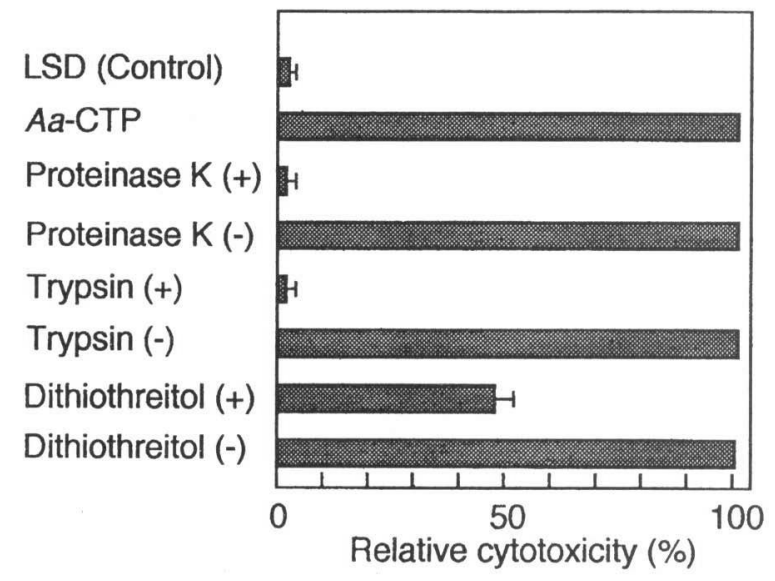

FIG. 3. Cytotoxicity of the Aa-CTP in cultured tobacco BY-2 cells. One hundred and eighty microliter aliquots of the BY-2 cell suspension $\left(6 \times 10^{5}\right.$ cells $/ \mathrm{ml}$, LSD medium) were combined with another $20 \mu \mathrm{I}$ of LSD medium containing $\mathrm{Aa}$-CTP treated under various conditions (final concn, $40 \mathrm{\mu} \mathrm{g} / \mathrm{ml}$ ). After incubation for $4 \mathrm{~h}$ at $28^{\circ} \mathrm{C}$, cytotoxicities were determined by a double staining procedure using FDA and PI. The Aa-CTP was digested with trypsin or proteinase $\mathrm{K}$ in 50 $\mathrm{mM}$ phosphate buffer $(\mathrm{pH}$ 7.0) at a protease/substrate ratio of $1 / 100$ at $28^{\circ} \mathrm{C}$ for $15 \mathrm{~h}$. Reduction of the cysteine residues by dithiothreitol was carried out under the same condition with an $A a-C T P /$ dithiothreitol ratio of $1 / 3$.

treatments at up to $100^{\circ} \mathrm{C}$ for 30 min or by overnight exposure to $\mathrm{pH}$ conditions as extreme as $\mathrm{pH} 2$ or $\mathrm{pH}$ 11 (results not shown). Reduction of the cysteine residues by dithiothreitol, however, reduced the cytotoxicity (Fig. 3). The remarkable stability of $\mathrm{Aa}$ CTP may be explained by its small size and the presence of intramolecular disulfide bridges (Broekaert et al., 1992; Habtemariam, 1996).

From these data, it appears that the Aa-CTP produced by $A$. alternaria grown in liquid culture is a thermo- and acid-stable, small-sized peptide-like toxin. As shown in Fig. 3, the cytotoxicity of Aa-CTP was abolished after treatment with trypsin The serine protease trypsin is specific for amides with positively charged side-chains (Lys or Arg). These results suggest that Aa-CTP contains Lys and/or Arg in the active site. In the scanning the literature, however, we found no reports describing a peptide-like toxin containing basic amino acids such as Lys and/or Arg from $A$. alternaria. However, due to the low levels of the putative toxin, purification and further analyses, including structural elucidation, were not carried out. Studies along these lines are now in progress.

\section{REFERENCES}

Abbas, H. K., Paul, R. N., Riley, R. T., Tanaka, T., and Shier, W. T. (1998) Ultrastructural effects of AAL-toxin TA from 
the fungus Alternaria alternata on black nightshade (Solanum nigrum L.) leaf discs and correlation with biochemical measures of toxicity. Toxicon, 36, 1821-1832.

Broekaert, W. F., Marien, W., Terras, F. R. G., De Bolle, M. F. C., Proost, P., Damme, J. V., Dillen, L., Claeys, M., Bees, S. B., Vanderleyden, J., and Cammue, B.P.A. (1992) Antimicrobial peptides from Amaranthus caudatus seeds with sequence homology to the cysteine/glycine-rich domain of chitin-binding proteins. Biochemistry, 31, 43084314.

Combina, M., Dalcero, A. M., Varsavsky, E., and Chulze, S. (1999) Effects of food preservatives on Alternaria alternata growth and tenuazonic acid production. Food Additives Contaminat., 16, 433-437.

Habtemariam, S. (1996) Cytotoxicity of extracts from the mushroom Paxillus involutus. Toxicon, 34, 711-713.

Hasan, H. A. (2001) Phytotoxicity of pathogenic fungi and their mycotoxins to cereal seedling viability. Microbiol. Immunol. Hung., 48, 27-37.

Ishida, S., Takahashi, Y., and Nagata, T. (1993) Isolation of cDNA of an auxin-regulated gene encoding a $G$ protein $\beta$ subunit-like protein from tobacco BY-2 cells. Proc. Nat/. Acad. Sci. USA, 90, 11152-11156.

Jones, K.H., and Senft, J.A. (1985) An improved method to determine cell viability by simultaneous staining with fluorescein diacetate-propidium iodide. J. Histochem. Cytochem., 33, 77-79.

Kodoma, M., Wada, H., Otani, H., Kohmoto, K., and Kimura, Y. (1998) 3,5-Di-o-caffeoylquinic acid, an infectioninhibiting factor from Pyrus pyrifolia induced by infection with Alternaria alternata. Phytochemistry, 47, 371-373.

Kohmoto, K., Akimitsu, K., and Otani, H. (1991) Correlation of resistance and susceptibility of citrus to Alternaria alternata with sensitivity to host-specific toxins. Phytopathology, 81, 719-722.

Kohmoto, K., Itoh, Y., Shimomura, N., Kondoh, Y., Otani, H., Kodama, M., Nishimura, S., and Nakatsuka, S. (1993) Isolation and biological activities of two host-specific toxins from the tangerine pathotype of Alternaria alternata. Phytopathology, 83, 495-502.
Knogge, W. (1996) Fungal infection of plants. Plant Cell, 8 , 1711-1722.

Koncewiz, M., Mathiaparanam, P., Uchytil, T. F., Sparapand, L., Tam, J., Rich, D. H., and Durbin, R. D. (1973) The sequence and optical configuration of amino acids in tentoxin. Biochem. Biophys. Res. Commun., 53, 653-658.

Li, F. Q., Toyazaki, N., and Yoshizawa, T. (2001) Production of alternaria mycotoxins by Alternaria alternata isolated from weather-damaged wheat. J. Food Prot., 64, 567-571.

Liakopoulou-Kyriakides, M., Lagopodi, A. L., Thanassoulopoulos, C. C., Stavropoulos, G. S., and Magafa, V. (1997) Isolation and synthesis of a host-selective toxin produced by Alternaria alternata. Phytochemistry, 45, 3740.

Liebermann, B., Ellinger, R., and Pinet, E. (1996) Isotentoxin, a conversion product of the phytotoxin tentoxin. Phytochemistry, 42, 1537-1540.

Linsmaier, M. L., and Skoog, F. (1965) Organic growth factor requirements of tobacco tissue cultures. Plant Physiol., 18, 100-127.

Meyer, W. L., Templeton, G. E., Grable, C. E., Siegel, C. W., Jones, R., Woodhead, S. H., and Sauer, C. (1971) The structure of tentoxin. Tetrahedron Lett., 25, 2357-2360.

Ramm, K., Ramm, M., Liebermann, B., and Reuter, G. (1994) Studies of the biosynthesis of tentoxin by Alternaria alternata. Microbiology (UK), 140, 3257-3266.

Suemitsu, R., Horiuchi, K., Kubota, M., and Okamatsu, T. (1990) Production of alterporriols, altersolanols and macrosporin by Alternaria porri and A. solani. Phytochemistry, 29, 1509-1511.

Steele, J. A., Uchytil, T. F., Durbin, R. D., Bhatnagar, P., and Rich, D. H. (1976) Chloroplast coupling factor 1. A species specific receptor for tentoxin. Proc. Natl. Acad. Sci. USA, 73, 2245-2248.

Walton, J. D. (1996) Host-selective toxins: Agents of compatibility. Plant Cell, 8, 1723-1733.

Yagi, A., Okamura, N., Haraguchi, H., Abo, T., and Hashimoto, K. (1993) Antimicrobial tetrahydroanthraquinones from a strain of Alternaria solani. Phytochemistry, 33, 87-91. 